Article

\title{
Assessment of the Future Impact of Climate Change on the Hydrology of the Mangoky River, Madagascar Using ANN and SWAT
}

\author{
Mirindra Finaritra Rabezanahary Tanteliniaina ${ }^{1}$, Md. Hasibur Rahaman ${ }^{2}{ }^{\mathbb{D}}$ and Jun Zhai ${ }^{1, *}$ \\ 1 MOE Key Laboratory of the Three Gorges Reservoir Region's Eco-Environment, Chongqing University, \\ Chongqing 400045, China; mirindra@cqu.edu.cn \\ 2 Department of Environmental Science and Technology, Jashore University of Science and Technology, \\ Jashore 7408, Bangladesh; hasib.est@just.edu.bd \\ * Correspondence: zhaijun@cqu.edu.cn; Tel.: +86-23-6512-0810 or +86-136-3796-6883; Fax: +86-23-6512-0810
}

check for

updates

Citation: Rabezanahary Tanteliniaina, M.F.; Rahaman, M.H.; Zhai, J. Assessment of the Future Impact of Climate Change on the Hydrology of the Mangoky River, Madagascar Using ANN and SWAT. Water 2021, 13, 1239. https:// doi.org/10.3390/w13091239

Academic Editors: José

María Senciales-González and

Athanasios Loukas

Received: 24 March 2021

Accepted: 28 April 2021

Published: 29 April 2021

Publisher's Note: MDPI stays neutral with regard to jurisdictional claims in published maps and institutional affiliations.

Copyright: (c) 2021 by the authors. Licensee MDPI, Basel, Switzerland. This article is an open access article distributed under the terms and conditions of the Creative Commons Attribution (CC BY) license (https:// creativecommons.org/licenses/by/ $4.0 /)$.

\begin{abstract}
The assessment of the impacts of climate change on hydrology is important for better water resources management. However, few studies have been conducted in semi-arid Africa, even less in Madagascar. Here we report, climate-induced future hydrological prediction in Mangoky river, Madagascar using an artificial neural network (ANN) and the soil and water assessment tool (SWAT). The current study downscaled two global climate models on the mid-term, noted the 2040s (2041-2050) and long-term, noted 2090s (2091-2099) under two shared socioeconomic pathways (SSP) scenarios, SSP 3-7.0 and SSP 5-8.5. Statistical indices of both ANN and SWAT showed good performance $\left(\mathrm{R}^{2}>0.65\right)$ of the models. Our results revealed a rise in maximum temperature $\left(4.26-4.69{ }^{\circ} \mathrm{C}\right)$ and minimum temperature $\left(2.74-3.01^{\circ} \mathrm{C}\right)$ in the $2040 \mathrm{~s}$ and $2090 \mathrm{~s}$. Under SSP 3-7.0 and SSP 5-8.5, a decline in the annual precipitation is projected in the 2040s and increased the 2090s. This study found that future precipitation and temperature could significantly decrease annual runoff by $60.59 \%$ and $73.77 \%$ in the 2040 s; and $25.18 \%$ and $23.45 \%$ in the 2090 s under SSP 3-7.0 and SSP 5-8.5, respectively. Our findings could be useful for the adaptation to climate change, managing water resources, and water engineering.
\end{abstract}

Keywords: climate change; downscaling; ANN; SWAT model; Africa

\section{Introduction}

As global environmental issues, climate change is anticipated to affect water resources and hydrology [1]. The basin hydrology is impacted by the rise in temperature and change in precipitation distribution, resulting in the alteration of water quantity and availability [2]. Evaluating the impacts of climate change on streamflow is the key to sustainable water resources management and efficient adaptation and mitigation strategies [1].

Significant temperature rise has been a common experience for several regions of the world; a rise is expected to continue in the future [3-6]. Regarding climate change at a regional scale, the tropical regions and the Sub-Saharan countries were considered one of the most vulnerable regions due to their weaker economies [7]. Overall in Africa, increased the near-surface temperature by $0.5^{\circ} \mathrm{C}$ has been recorded during the last 5 decades [5]. Among them, Madagascar is highly vulnerable to climate change and natural catastrophe as it is located in the Indian Ocean and with $5000 \mathrm{~km}$ of coastline [8]. Floods often occur in the North and Northeast, while drought conditions are present in the certain southern region [9]. In Madagascar, climate change will negatively influence hydrological processes and streamflow regimes.

Mangoky river is the longest and most important river in Madagascar. The Mangoky river is located in a semi-arid region in the southwest part of Madagascar [10]. Understanding the impact of climate change on the hydrology in this river will provide useful 
insight for better water management and engineering for the semi-arid regions, given that the hydrology in the semi-arid is highly sensitive to climate change. A previous study conducted in semi-arid and arid regions showed that climate change would worsen water scarcity [11]. A study conducted on the semi-arid basin in Mexico showed decreased runoff by about $60 \%$ due to climate change [12]. Despite the importance of the research in the semi-arid regions, a study conducted in the African rivers is rare. To the best of our knowledge, no research has been reported on the hydrological responses to future climate change in the Mangoky river, Madagascar.

General circulation models (GCMs) are the most up to date accessible instrument for acquiring the projections of climate change at the global level [13], but their large resolution $(250 \mathrm{~km}$ to $600 \mathrm{~km})$ [14] makes them unreliable for a study that requires finer resolution such as hydrology [15]. The downscaling technique is one approach that can be used to reduce the coarse resolution of GCMs [16-18]. Therefore, in this study, we used an artificial neural network (ANN) to downscale outputs from the latest generation of coupled model intercomparison project (CMIP6). Compared to the previous version, CMIP6 is more skillful and showed better improvement [19-21].

A hydrological model can provide consistent information about the impact of climate change on the hydrology of a river [22]. In the present study, the soil and water assessment tool (SWAT) model was chosen to model the future flows under climate change. SWAT has been commonly used and successfully applied worldwide [23-27], but SWAT is limited in the African region. Besides, this is the first attempt to use SWAT in Madagascar. This research is the first to use a computer-based hydrological model and modeling runoff in a river in Madagascar.

This study aims to assess and explore the impact of climate change on the hydrological regime at the Mangoky river by using ANN for downscaling and the SWAT model for hydrological simulation. The specific objectives of the present study are: (1) to downscale the GCMs outputs for the Mangoky river using ANN and project the future climate in the river under both SSP3-7.0 and SSP5-8.5 emissions scenarios. It is worth noting that we do not discuss the likelihood of the two scenarios to occur in the future. We used them to explore and understand the hydrological responses if the world would follow the fossil-fuel emission as simulated with these two scenarios. (2) to calibrate and evaluate the performance of the SWAT model, (3) to assess the impact of future climate change on hydrology in a semi-arid region.

\section{Materials and Methods}

\subsection{Study Area}

The Mangoky river is located on the southwest coast of Madagascar. The study area lies between $43.26^{\prime}$ and $47.26^{\prime} \mathrm{E}$ and $21^{\circ} 15^{\prime}$ and $22^{\circ} 35^{\prime} \mathrm{S}$. The climate at the Mangoky river is a tropical semi-arid, with a mean annual rainfall of about $600 \mathrm{~mm} /$ year distributed from November to March. Mangoky basin is about $55,750 \mathrm{~km}^{2}$. The Mangoky river is the longest river in Madagascar (564 km) which flows from the central highland in Madagascar to the Mozambique channel (Figure 1). 


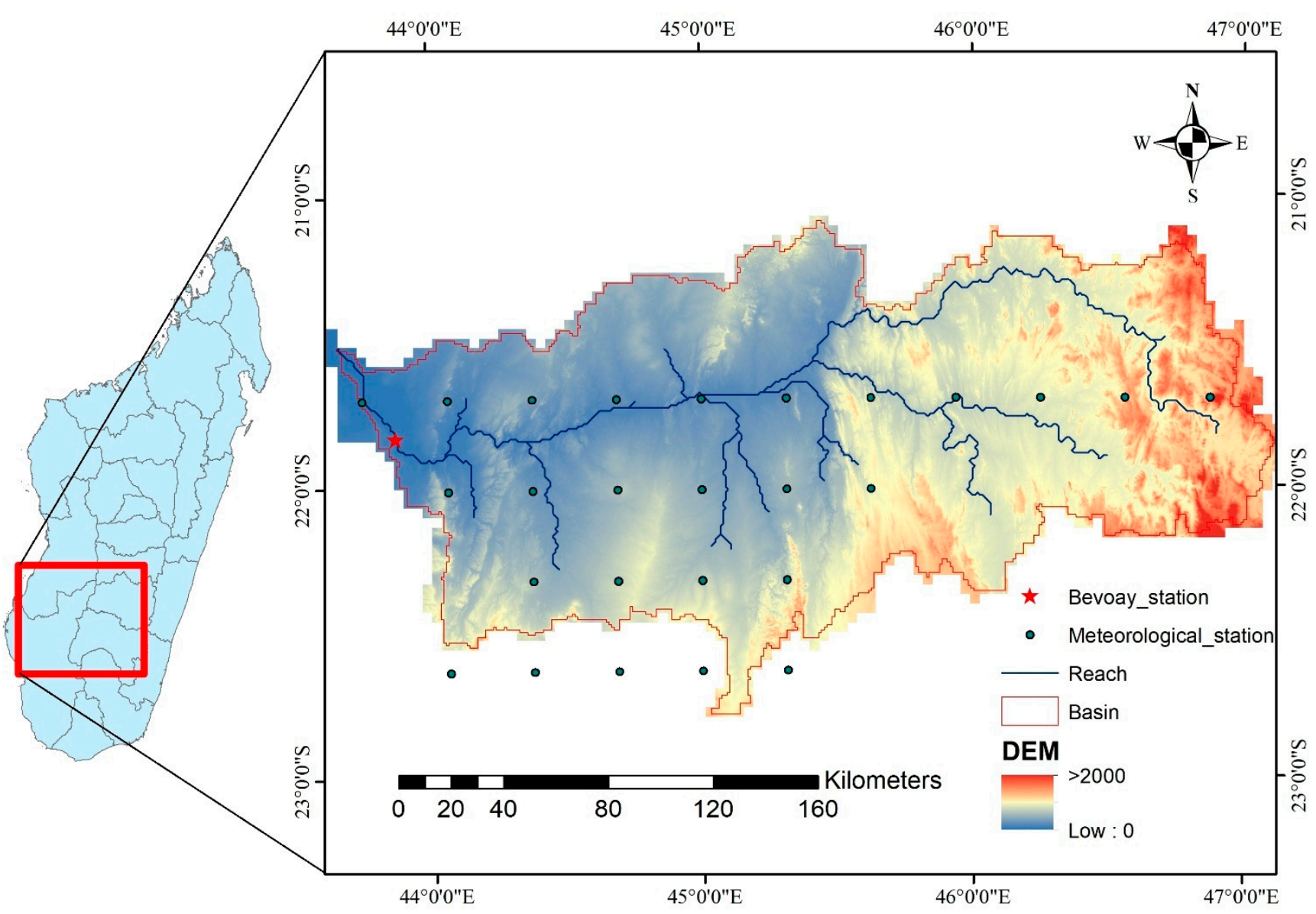

Figure 1. Location map and DEM of the Mangoky river in Madagascar.

\subsection{Data Collection}

\subsubsection{Meteorological Data}

In the downscaling procedure, two types of data were needed: the predictand data or target data (observed temperature and precipitation) and predictor data representing the large-scale data (GCM). Observed daily maximum temperature, minimum temperature, and precipitation of 25 meteorological stations were collected from the National Centers for Environmental Prediction Climate Forecast System Reanalysis (NCEP/CSFR). We used daily meteorological data collected from 1979-2013. However, meteorological data after 2013 is available only monthly and therefore discarded for the present study. Standardized reanalysis predictors data were obtained from the National Centers for Environmental Prediction (NCEP/NCAR), with a spatial resolution of $2.5^{\circ} \times 2.5^{\circ}$. A total of 26 predictors covering different pressure, airflow velocity, wind directions, divergence, relative humidity, air temperature data were collected from NCEP/NCAR. Detail list of predictors, including their code, can be found in supplementary material Table S1. These two data were used to train the ANN. Further details about training an ANN for downscaling can be found in Abrahart et al., 2004; Nourani et al., 2019; Vu et al., 2016 [28-30]. Before analysis, our data were quality-controlled. We checked for outliers and the homogeneity of the data using Xlstat.

The trained ANN was fed with predictors from CMIP6 to project future temperature and precipitation. We used global climate data from two GCMs: The Norwegian Earth System Model version 2 (NorESM 2) with a resolution of $2.5^{\circ} \times 1.9^{\circ}$ developed by the Norwegian Climate Consortium [31]; and the Canadian Earth System Model version 5 (CanESM5) with a resolution of $2.8^{\circ} \times 2.8^{\circ}$, developed by the Canadian Climate Centre [32]. 
It should be noted that even with some biases, previous studies using CMIP to reproduce observed historical data have shown great performance in the regional hindcast run [15,21].

The GCMs were re-gridded to have the same resolution as the NCEP/NCAR predictors using the inverse distance weighted (IDW). These two GCMs were collected from the website of the Earth System Grid Federation (ESGF). In this study, we considered two different shared socioeconomic pathways (SSP): SSP 3-7.0 (regional rivalry) and SSP 5-8.5 (fossil fuel development) [33]. The latest CMIP6 combines representative concentration pathways (RCP) and SSP to make future scenarios more reasonable and reliable [34]. 2016). SSP 3-7.0 is the new scenario added to the CMIP6 compared to the previous version (CMIP5), it reflects more plausible outcomes, and its use is recommended [35]. SSP3-7.0 represents the middle range of baseline describing geographical competitiveness and difficult pathways (important challenges to mitigation and adaptation). In contrast, SSP5-8.5 represents the highest emission scenario describing a rapid development based on using fossil fuel (High challenges to mitigation, low challenges to adaptation) [33]. A detailed explanation of SSP can be found elsewhere [36]. It is worth noting that not all the predictors from NCEP/NCAR were available from the GCMs. Therefore, predictors should be chosen cautiously [30].

\subsubsection{SWAT Input}

To run, SWAT requires a diversity of information related to meteorology, land use, soil, and agriculture $[25,37,38]$. In general, SWAT needs spatial data and attribute databases, which mainly include: Digital elevation model DEM (Figure 1), Land use and land cover (LULC) (Supplementary Material Figure S1), soil attribute data (Supplementary Material Figure S2 and Table S2), hydrological data, and meteorological data. Table 1 summarizes the data source and resolution of the data used in SWAT.

Table 1. Description of the input data used in SWAT.

\begin{tabular}{ccc}
\hline Data & Resolution/Date & Source \\
\hline DEM & $30 \mathrm{~m} \times 30 \mathrm{~m}$ & NASA \\
LULC & $800 \mathrm{~m}$ & SWAT land use database \\
Soil map & $5 \mathrm{~km}$ & FAO-soil database \\
Meteorological data & $1979-2013$ & NCAR/CSFR and Madagascar National \\
& & $\begin{array}{c}\text { Meteorological and Hydrological Service } \\
\text { Global runoff database/Madagascar } \\
\text { Monthly observed runoff }\end{array}$ \\
& $1982-1995$ & $\begin{array}{c}\text { National Meteorological and } \\
\text { Hydrological Service }\end{array}$ \\
\hline
\end{tabular}

\subsection{Methods}

\subsubsection{Screening for Predictors}

The performance of the ANN to downscale GCM depends mainly on the choice of appropriate predictors. Using all predictors in the final model is not recommended and redundant because some of the predictors are intercorrelated. The predictors-predictand relations in this research were established using the correlation coefficient. The correlation test resulted in the most powerful predictors to be used as input for the ANN. The following characteristics should be considered: "(1) physically and conceptually sensible concerning the predictand, (2) readily available from archives of observed data and GCM outputs, and (3) accurately modeled by GCMs" [30]. We selected 3 to 5 predictors as inputs variable for the ANN model of each station.

\subsubsection{Artificial Neural Network}

The ANN is a network of interconnected neurons, a computing system created to process information like the human brain [28,29] (Supplementary Material Figure S3). ANN is increasingly preferred $[13,30,39,40]$ because it is inexpensive but efficient $[13,41]$. The ANN model developed and used in this study was a back-propagation algorithm 
feed-forward network (FNN-BP) [42,43] with three layers: an input layer, a hidden layer, and an output layer where each layer is connected by weights. The optimal set of weights is determined through the learning process, which consists of training ANN with known input and output values. The three-layer FNN-BP network model in this study was trained using the Levenberg-Marquardt optimization algorithm [29,40]. In this study, we used the sigmoid and linear transfer function in the hidden and output layer.

The number of hidden layers used in the ANN is important because an excessive hidden layer will cause over-fitting [44], which means that the network overestimated the complexity of the problem. With our problem, only one hidden layer was needed, and increasing the number of layers did not significantly improve the output from the model. Rather it increases the complexity of the model and the risk of overestimation. The calculation in the ANN is given by Equation (1):

$$
\hat{y}=g\left(w_{k} f\left(\sum_{j=1}^{n} v_{i j} x_{i}+b_{j}\right)+b_{k}\right)
$$

where $\hat{y}$ is the predicted variable (temperature/precipitation), $b_{j}$ and $b_{k}$ is the bias, $x_{i}$ is the inputs variable (predictors), $\mathrm{w}_{\mathrm{k}}$ and $\mathrm{v}_{\mathrm{i}}$ are the weights, $\mathrm{g}$ and $\mathrm{f}$ are the transfer function (logsig and purelin).

\subsubsection{Bias Correction}

Before feeding the downscaled climatic data to the hydrological model, the outputs (predicted precipitation and temperature) must go through a bias correction process. In this study, we used the linear scaling correction. The correction in precipitation used a multiplier, and the temperature used the additive term as given by Equations (2) and (3):

$$
\begin{gathered}
\mathrm{T}_{\text {cor }}=\mathrm{T}_{\text {pred }}+\left(\overline{\mathrm{T}}_{\text {obs }}-\overline{\mathrm{T}}_{\text {pred }}\right) \\
\mathrm{P}_{\text {cor }}=\mathrm{P}_{\text {pred }} \times \frac{\overline{\mathrm{P}}_{\text {obs }}}{\overline{\mathrm{P}}_{\text {pred }}}
\end{gathered}
$$

where $\mathrm{T}_{\text {cor }}$ and $\mathrm{P}_{\text {cor }}$ : the temperature and precipitation bias-corrected, $\mathrm{T}_{\text {pred }}$ and $\mathrm{P}_{\text {pred }}$ : the downscaled data, and $\mathrm{T}_{\mathrm{obs}}$ and $\mathrm{P}_{\mathrm{obs}}$ are the observed data.

\subsubsection{SWAT Model}

SWAT hydrological model is a semi-distributed and dynamic hydrologic and water quality model developed by the United States Department of Agriculture, Agricultural Research Service (USDA-ARS) for watershed-scale [25]. In SWAT, the catchment is split up into sub-basins divided into a smaller unit called hydrological response unit (HRU) [45]. HRU is defined by consolidating the same LULC, soil type, and optionally inclination characteristics; it is the smallest unit involved in the hydrological calculation. The water balance at the HRU level is calculated using Equation (4), and the outputs are aggregated at the sub-basin level [22]:

$$
\mathrm{SW}_{\mathrm{t}}=\mathrm{SW}_{0}+\Sigma_{\mathrm{i}=1}^{\mathrm{t}}\left(\mathrm{R}_{\text {day }}-\mathrm{Q}_{\text {surf }}-\mathrm{E}_{\mathrm{a}}-\mathrm{W}_{\text {seep }}-\mathrm{Q}_{\mathrm{gw}}\right)
$$

With $\mathrm{SW}_{\mathrm{t}}$ : the final soil water content $\left(\mathrm{mm} \mathrm{H}_{2} \mathrm{O}\right), \mathrm{SW}_{0}$; the initial soil water content ( $m m \mathrm{H}_{2} \mathrm{O}$ ), t: the time (days), $\mathrm{R}_{\text {day }}$ : the amount of precipitation on day $\mathrm{i}\left(\mathrm{mm} \mathrm{H}_{2} \mathrm{O}\right), \mathrm{Q}_{\text {surf }}$ : the amount of surface runoff on day $\mathrm{i}\left(\mathrm{mm} \mathrm{H}_{2} \mathrm{O}\right), \mathrm{E}_{\mathrm{a}}$ : the amount of evapotranspiration on day $\mathrm{i}\left(\mathrm{mm} \mathrm{H}_{2} \mathrm{O}\right), \mathrm{W}_{\text {seep }}$ : the amount of percolation and bypass flow exiting the soil profile bottom on day $\mathrm{i}\left(\mathrm{mm} \mathrm{H}_{2} \mathrm{O}\right), \mathrm{Q}_{\mathrm{gw}}$ is the amount of return flow on day $\mathrm{i}\left(\mathrm{mm} \mathrm{H}_{2} \mathrm{O}\right)$.

To estimate the surface runoff, a modified soil conservation service curve number is applied by the SWAT model $[22,25]$. SWAT model has three different techniques for calculating evapotranspiration: Priestley-Taylor, Hargreaves, Penman-Monteith method, 
and we used the latter in this study. A comprehensive explanation of the hydrological model SWAT is available in J. G. Arnold et al., 2012; Neitsch et al., 2011 [25,45].

\subsubsection{ANN and SWAT Model Calibration and Validation}

The qualitative performance of the ANN model was assessed using the coefficient of determination $\left(R^{2}\right)$. If the $R^{2}$ was satisfactory $\left(R^{2}>0.50\right)$, we stopped the training, which indicated that the ANN is sufficiently trained and is ready for use. However, if the $\mathrm{R}^{2}$ was lower than 0.50, the ANN was re-trained.

The goodness of fit of the SWAT model was estimated using $\mathrm{R}^{2}$, Nash and Sutcliffe efficiency (NSE) shown in Supplementary Material Equation (S1), and PBIAS is given by Supplementary Material Equation (S2). The SWAT performance was assessed using the criteria given by [46] (Table 2). The SWAT calibration and uncertainty program (SWATCUP) was used to calibrate and validate SWAT. The sequential uncertainty fitting (SUFI2) was selected among all the algorithm provided by SWAT-CUP. The general research methodology followed in this study is summarized in Supplementary Material Figure S4.

Table 2. SWAT model evaluation criteria based on [46].

\begin{tabular}{ccc}
\hline Variable & Value & Performance Rating \\
\hline \multirow{2}{*}{ NSE } & $>0.65$ & Very good \\
& 0.54 to 0.65 & Good \\
& $<0.5$ & Satisfactory \\
P-BIAS & $<20 \%$ & Very good \\
& $20 \%$ to $40 \%$ & Good \\
& $>40 \%$ & Unsatisfactory \\
$\mathrm{R}^{2}$ & $\mathrm{R}^{2}>0.7$ & Very good \\
& $0.5<\mathrm{R}^{2}<0.7$ & Good \\
$\mathrm{R}^{2}<0.5$ & Satisfactory \\
\hline
\end{tabular}

\section{Results and Discussion}

\subsection{Selection of Predictors}

In this study, the correlation matrix was used to select the set of predictors to be used as inputs for the downscaling with ANN (Supplementary Material Table S3). It is recommended to use more than just one predictor since the combination of predictors has stronger correlations with downscaled results, but using many predictors lowered the correlations [47]. Thus, we chose 3 to 5 predictors with the highest correlation coefficient with the temperature and precipitation at each station. The selected predictors were used as input during the training of the ANN. The set of predictors may vary from station to station, but the results are relatively consistent between stations. Overall, surface temperature (temp), geopotential height (p_500, p_850), humidity (rhum, shum) are common predictors for maximum and minimum temperature; surface temperature (temp), geopotential height (p_500, p_850), near-surface humidity (rhum, shum), and mean sea level pressure (mslp) are common predictors for precipitation.

\subsection{ANN and SWAT Model Assessment}

\subsubsection{ANN Performance}

The goodness, precision, and reliability of the climate projections depend mainly on the performance of the ANN. The ANN performance was good for both precipitation and temperature. The $R^{2}$ (at randomly chosen station id 214447) for the precipitation, maximum temperature, and minimum temperature was $0.79,0.80$, and 0.92 , respectively (Supplementary Material Figure S5). In general, precipitation is one of the most difficult climate variables to downscale and great uncertainties still affect the performances of both stochastic and deterministic precipitation prediction models. However, the $\mathrm{R}^{2}$ indicates the good performance of the ANN in downscaling precipitation. 


\subsubsection{SWAT Model Calibration and Validation}

The SWAT model was calibrated from 1982-1988. The model was warmed up during the first three years, i.e., 1979 to 1981, and validated from 1989-1995 (Figure 2). Due to the unavailability of observed runoff data, we could not carry out the calibration and validation of SWAT from 1996-2013. However, 7 years of calibration and 7 years of validation should serve our current SWAT modeling purpose.

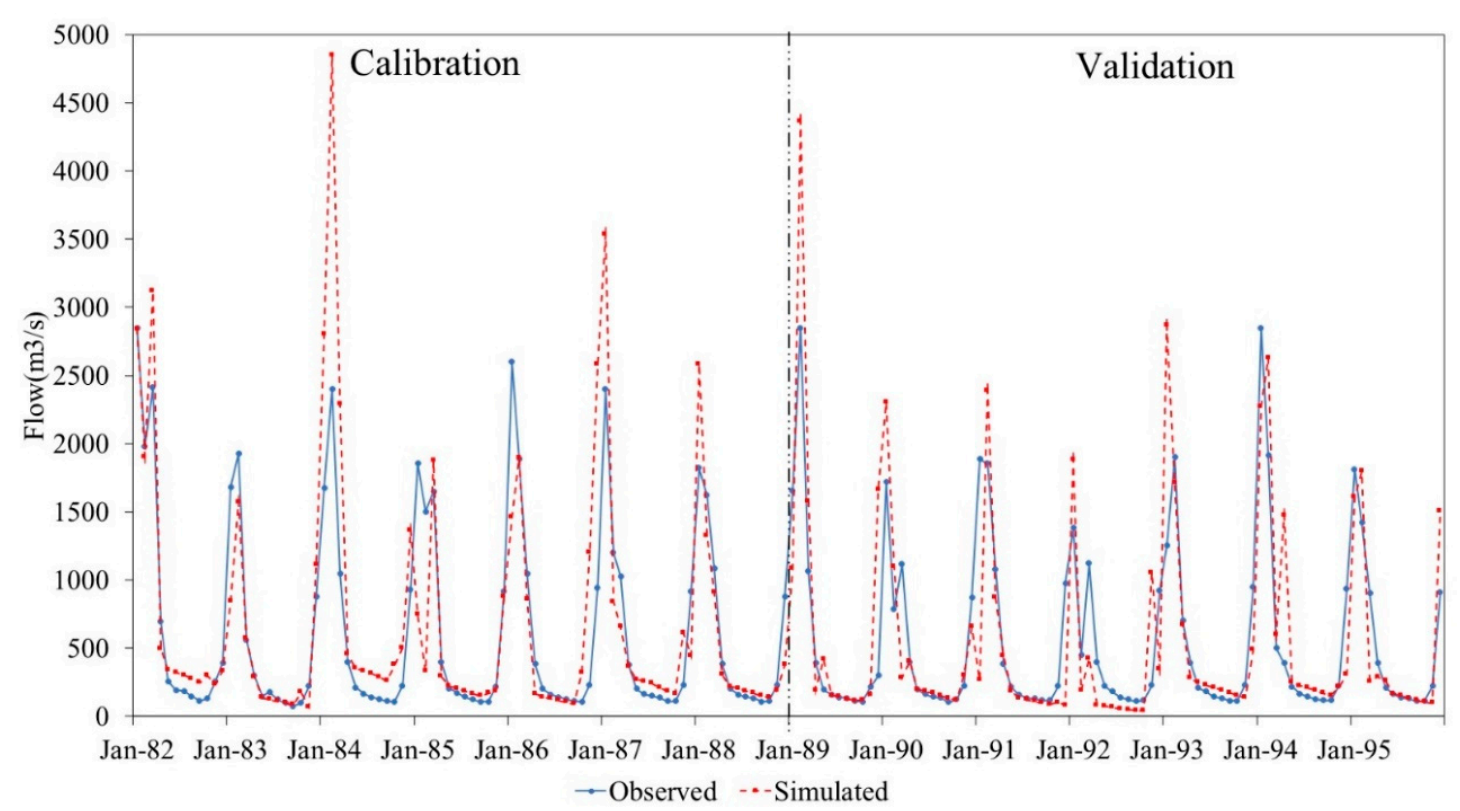

Figure 2. Observed and simulated runoff during the calibration and validation at the Mangoky river.

Altogether, 10 parameters were used to calibrate the SWAT model. Their description and fitted values are outlined in Table 3. The SWAT statistical performance during calibration and validation was good.

Table 3. Parameters selected for the calibration and validation of the SWAT model at Mangoky river, using SUFI-2.

\begin{tabular}{|c|c|c|c|}
\hline Inputs Variable Name & Variable Description & Fitted Value & Method of Change \\
\hline CN2.mgt & Curve number & 0.18 & Relative $^{1}$ \\
\hline ALPHA_BF.gw & Baseflow alpha factor (1/days) & 0.55 & Replace $^{2}$ \\
\hline GW_DELAY.gw & Groundwater delays time (days) & 180 & Replace \\
\hline GWQMN.gw & $\begin{array}{l}\text { Threshold depth of water in the shallow aquifer } \\
\text { required for return flow to occur }\left(\mathrm{mmH}_{2} \mathrm{O}\right) \text {. }\end{array}$ & 175 & Replace \\
\hline ESCO.bsn & Soil evaporation compensation factor & 0.45 & Replace \\
\hline SURLAG.bsn & Surface runoff lag coefficient & 4.15 & Replace \\
\hline CH_K2.rte & $\begin{array}{l}\text { Effective hydraulic conductivity in main channel } \\
\text { alluvium (mm/hr) }\end{array}$ & -0.1 & Relative \\
\hline SOL_AWC.sol & $\begin{array}{l}\text { Available water capacity of the soul layer } \\
\qquad\left(\mathrm{mmH}_{2} \mathrm{O} / \mathrm{mmsoil}\right)\end{array}$ & -0.27 & Relative \\
\hline GW_REVAP.gw & Groundwater revap coefficient & 0.17 & Replace \\
\hline RCHRG_DP.gw & Deep aquifer percolation fraction & 0.75 & Replace \\
\hline
\end{tabular}

${ }^{1}$ relative change of spatial parameters and multiplies the existing parameter's value by $\left(1+\right.$ an increment); ${ }^{2}$ replace the value of the parameters by the fitted value.

The statistical performance of SWAT during the calibration and validation are summarized in Table 4. During the calibration, the daily NSE of 0.52 suggested that the model was well-calibrated. The PBIAS is relatively small indicated good agreement in the flow volume [23]; the same results can be deduced from the value $R^{2}$ of 0.70 . The validation also showed a good performance with NSE 0.47, PBIAS 2.9\%, and $R^{2} 0.66$. 
Table 4. Performance of the SWAT model during the calibration and validation.

\begin{tabular}{cccc}
\hline & $\mathbf{R}^{\mathbf{2}}$ & NSE & PBIAS \\
\hline Calibration & 0.70 & 0.52 & -12.20 \\
Validation & 0.66 & 0.47 & -2.90 \\
\hline
\end{tabular}

\subsection{Future Climate in the Mangoky}

\subsubsection{Future Precipitation}

In this study, the change in average future precipitation was measured regarding baseline precipitation (1982-2013) in mid-term 2040s (2040-2050); and long-term 2090s (2090-2100). The ensemble from NorESM and CanESM was estimated by simple aggregation. Table 5 displays the relative change in annual precipitation in the $2040 \mathrm{~s}(-6.75 \%$ and $-17.44 \%$ ) and in the 2090s (35.74\% and 52.61\%) under SSP3-7.0 and SSP5-8.5, respectively. The annual precipitation at the Mangoky is projected to decrease in the 2040s but increase in the 2090s, indicating a serious drought in the mid-21st century. The intensity and severity of future drought may vary from region to region. However, previous studies agree with the increase in drought in the 21st century over most parts of Africa [48,49].

Table 5. Absolute change in annual temperature (Tmax and Tmin) and relative change in precipitation in the 2040s and 2090s regarding the baseline (1982-2013).

\begin{tabular}{ccccccc}
\hline & \multicolumn{2}{c}{ Precipitation (\%) } & \multicolumn{2}{c}{ Tmax $\left({ }^{\circ} \mathbf{C}\right)$} & \multicolumn{2}{c}{ Tmin $\left({ }^{\circ} \mathbf{C}\right)$} \\
\hline & SSP 3-7.0 & SSP 5-8.5 & SSP3-7.0 & SSP5-8.5 & SSP3-7.0 & SSP5-8.5 \\
Change 2040s & -6.75 & -17.44 & 2.59 & 2.42 & 1.05 & 0.85 \\
Change 2090s & 35.74 & 52.61 & 4.26 & 4.69 & 2.74 & 3.01 \\
\hline
\end{tabular}

In the Mangoky river, most of the rain (>90\%) falls between November and March [10]. The rest of the year is considered a dry season or winter with less than $10 \%$ of the precipitation. Seasonal changes in precipitation are summarized in Table 6 . Seasonal changes in precipitation were calculated as the difference between future seasonal precipitation and the seasonal precipitation in the baseline. Like the change in the annual precipitation, in the 2040s, the summer precipitation is projected to decrease, but in the 2090s, increased summer precipitation will be expected. The change in summer precipitation will be significantly higher under SSP $5-8.5(p<0.0001)$ and higher in the 2090s $(p<0.0001)$. In winter, the precipitation will increase under the two-time horizons, with a higher increase in the 2090s $(103.5 \%$ and $111.25 \%)$ $(p<0.0001)$. These findings suggest that climate change will affect the seasonal distribution of precipitation in the Mangoky river. In the 2040s, the GCMs agree to a reduction in annual and summer precipitation and a rise in precipitation in winter. An increase in annual and seasonal precipitation is expected under both scenarios in the 2090s, suggesting stronger precipitation anomalies at the end of the 21st century [50,51]. A previous study also found a decrease in future precipitation during the beginning of the summer, suggesting a delay at the beginning of the wet period over some parts of southern Africa [5]. In line with a previous study conducted in Southern Africa, our findings suggest a major decrease in precipitation in the mid-21st century [3]. However, increased heavy precipitation and a number of extreme wet days are projected over Africa at the end of the 21st century [52,53].

Table 6. Relative change in seasonal precipitation and absolute change in seasonal temperature.

\begin{tabular}{cccccccc}
\hline & \multicolumn{2}{c}{ Precipitation } & \multicolumn{2}{c}{ Tmax } & \multicolumn{2}{c}{ Tmin } \\
\hline & & Summer (\%) & Winter (\%) & Summer $\left({ }^{\circ} \mathbf{C}\right)$ & Winter $\left({ }^{\circ} \mathbf{C}\right)$ & Summer $\left({ }^{\circ} \mathbf{C}\right)$ & Winter $\left({ }^{\circ} \mathbf{C}\right)$ \\
\hline \multirow{2}{*}{$2040 s$} & Baseline (mm) & 887.6 & 75.9 & 30.9 & 27.6 & 20.2 & 14.8 \\
\multirow{2}{*}{$2090 s$} & SSP 3-7.0 & -18.35 & 18.13 & 1.6 & 3.6 & -0.2 & 2.3 \\
& SSP 5-8.5 & -29.08 & 14.8 & 1.3 & 3.6 & -0.8 & 2.1 \\
& SSP 3-7.0 & 16.47 & 103.85 & 3.7 & 4.9 & 3.9 & 2.1 \\
\hline
\end{tabular}




\subsubsection{Future Temperature}

Both CanESM and NorESM projected a rise in future maximum temperature and minimum temperature. The absolute change in average annual maximum and minimum temperature is shown in Table 5. A rise in annual maximum and minimum temperature is expected under both SSP 3-7.0 and SSP 5-8.5 scenarios. In the 2090s, the increment in maximum temperature $\left(4.26^{\circ} \mathrm{C}\right.$ and $\left.4.69^{\circ} \mathrm{C}\right)$ is expected to be significantly higher than in the 2040s $\left(2.59{ }^{\circ} \mathrm{C}\right.$ and $\left.2.42{ }^{\circ} \mathrm{C}\right)(p<0.0001)$. Similar results are projected for the annual minimum temperature. The maximum and minimum temperature are both expected to greatly increase under SSP 5-8.5, suggesting that the continued increase in GHG emission will lead to a further rise in temperature. Our finding is consistent with Tadross et al., 2008 [9] and Nematchoua et al., 2018 [54], which found that minimum and maximum temperature in Madagascar are expected to increase with the increase in minimum temperature to exceed $1.5^{\circ} \mathrm{C}$ and maximum increases about $2.6^{\circ} \mathrm{C}$. An important increase in temperatures over several countries in Africa is projected with CMIP6 compared to the previous generation CMIP5 [3].

For the seasonal temperature, increased maximum temperature will be more important in winter with an increase of about $5.3^{\circ} \mathrm{C}$ in the 2090s, under SSP 5-8.5. The maximum summer temperature is projected to rise by $4.1^{\circ} \mathrm{C}$ in the 2090s under SSP 5-8.5. An increase in the minimum temperature is also anticipated to be more important in winter. However, a decrease in minimum temperature is projected in summer in the 2040s. This decrease in minimum temperature suggests a cooling from the surface water near the coast, neutralizing the warming effect [55]. The highest increase in seasonal minimum temperature is projected under SSP5-8.5 in the 2090s, with an increase of about $4.2^{\circ} \mathrm{C}$. Consistent with previous studies, we found that seasonal and annual temperatures in Africa are expected to increase rapidly than the global average in the 21st century [5]. A previous study using the CMIP5 showed that the increase in temperature would be $2{ }^{\circ} \mathrm{C}$ higher than the 20th-century baseline in the mid-21st century and $4^{\circ} \mathrm{C}$ higher at the end of the 21st century [5]. Over the Southern part of Africa, the annual and seasonal temperature is expected to top the global mean $[5,56]$. The average temperature in Southern Africa will increase by about $2.5^{\circ} \mathrm{C}$ to $3^{\circ} \mathrm{C}$ by 2100 [5], suggesting that the temperature in the Mangoky will exceed the mean temperature in Southern Africa.

\subsubsection{Climate Change Impact on Streamflow}

This section describes the future change in the surface runoff if the world would behave as simulated with SSP 3-7.0 and SSP 5-8.5. The water balance components in a watershed can be impacted by climate change, especially if the basin is located in the arid or semi-arid region. Climate change is expected to alter the flow regime of a river [23]. Table 7 shows the future change in runoff at the Mangoky river under SSP 3-7.0 and SSP 5-8.5. Figure 3 shows the surface runoff in the Mangoky river under the two chosen scenarios SSP 3-7.0 and SSP 5-8.5, in the 2040s and 2090s.

Table 7. Annual and seasonal relative change in average runoff at Mangoky.

\begin{tabular}{ccccc}
\hline & \multicolumn{2}{c}{ 2040s } & \multicolumn{2}{c}{ 2090s } \\
\hline & SSP 3-7.0 & SSP 5-8.5 & SSP 3-7.0 & SSP 5-8.5 \\
\hline Annual runoff (\%) & $-60.59^{* *}$ & $-73.77^{* *}$ & -25.18 & -23.45 \\
Summer runoff (\%) & $-62.84^{* *}$ & $-69.82^{* *}$ & -33.08 & -18.69 \\
Winter runoff (\%) & -27.01 & -88.42 & 62.95 & -20.12 \\
\hline
\end{tabular}

** significant at 0.05 and 0.1 .

In this study, the change in the future runoff was calculated regarding the average annual runoff of $589.28 \mathrm{~m}^{3} / \mathrm{s}$. Under both scenarios, the average runoff is projected to decrease in the 2040s, and in the 2090s, with a significant decrease in the 2040s $(p<0.0001)$. Resulting from the decrease in precipitation in the 2040s, an important decrease in surface runoff in the Mangoky river is projected in the mid-term future. While the increase in 
precipitation in the 2090s should result in increased runoff, we found a decrease in the runoff in the 2090s. This could be correlated with larger evapotranspiration due to the rise in maximum and minimum temperature [23]. Similar to our findings, the annual average river runoff over some dry regions, dry tropics, and Southern Africa are expected to experience water scarcity by the mid-21st century [57].
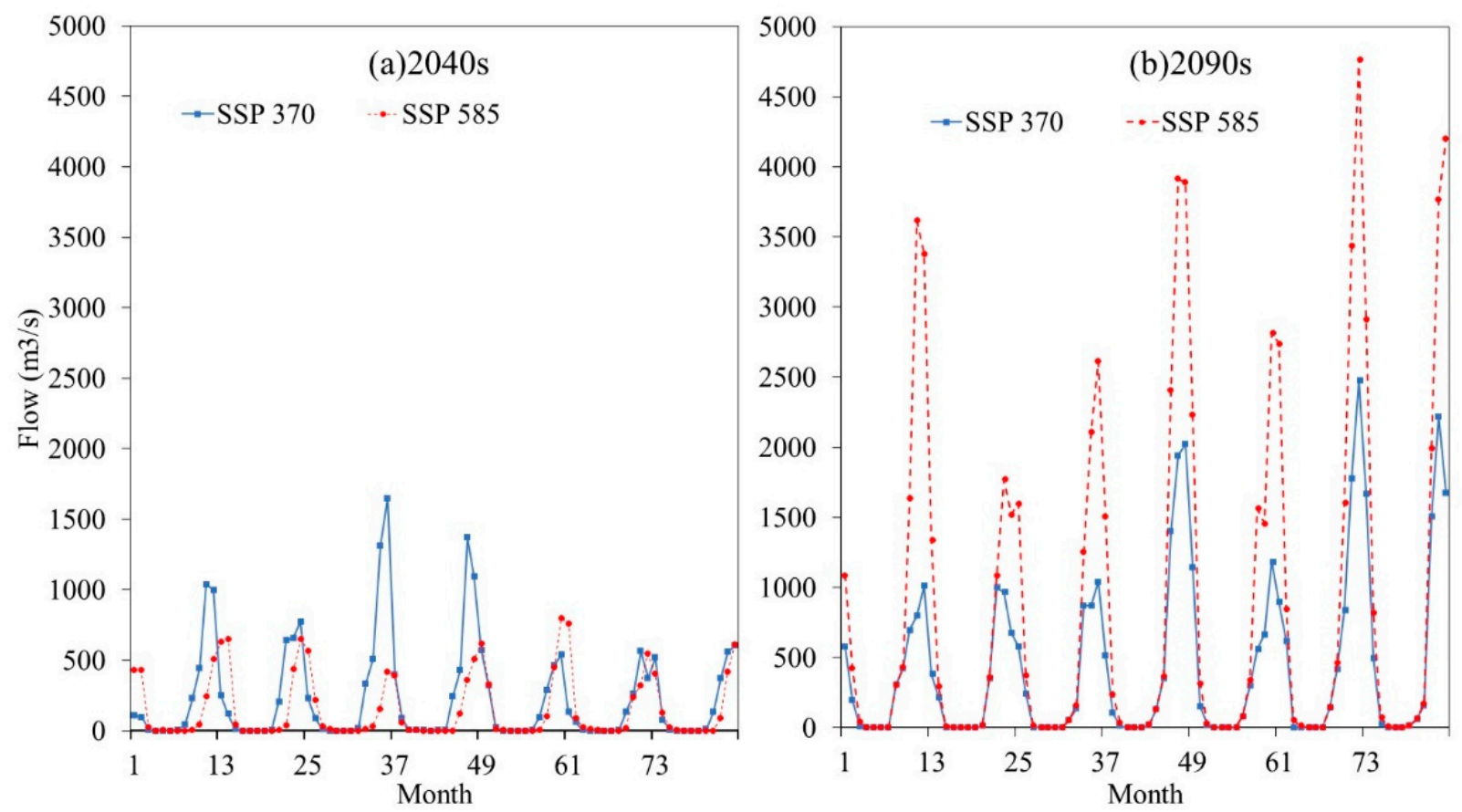

Figure 3. Future surface runoff at the Mangoky river under SSP 3-7.0 and SSP 5-8.5 in the (a) 2040s and (b) 2090s.

Seasonal runoff is also influenced by the change in precipitation and temperature. As a consequence of the decrease in seasonal precipitation in the 2040s, both winter and summer runoff is expected to decrease with a significant change under SSP $5-8.5(p<0.0001)$. In the 2090s, a similar change will be observed with the summer runoff. However, in the 2090s, increased winter runoff is expected under SSP 3-7.0 due to increased precipitation by about $103.85 \%$. In the 2090 s, under SSP $5-8.5$, even with increased precipitation, the important increase in temperature will increase evapotranspiration. Hence the runoff will decrease. Our findings suggest that more serious changes in the surface will happen in summer with a major reduction in streamflow.

Surface runoff has a powerful correlation with temperature and precipitation [1]. Therefore, a change in those two climates variable is expected to impact the runoff and availability of water resources in the semi-arid region of Madagascar. Climate change, primarily reduced precipitation and increased temperatures, is likely to affect water resources and associated sectors such as agriculture, household consumption, and energy generation in the Mangoky river. A rise in temperatures combined with a decrease in precipitation will reduce the availability of water resources, exacerbate the water scarcity, and increase demand for water resulting in a further water shortage in the semi-arid regions [9].

The findings of this study will be valuable for decision-making in the arid and semiarid regions, especially in Africa, where research on the impact of climate change is lacking. The change in the hydrology in a semi-arid region will follow the change in precipitation, but a higher increase in temperature will lead to a reduction in runoff. Future engineering in the semi-arid regions should be designed and adapted to the likely future climate condition to limit the impact of climate change on the water resources.

In this study, we considered the impact of climate change on water resources. However, several parameters like LULC may evolve and affect hydrology. The change in LULC will influence the flow of a river by changing the evapotranspiration [58,59]. However, 
the impact of climate change on hydrology is stronger than the impact of the change in LULC [59].

We also found that the high-emission narrative SSP 5-8.5 may overestimate future climate change, in line with Pielke Jr. and Ritchie [60] and Burgess et al. [61]. Thus, outputs from the high fossil fuel narrative can be described as high-risk future, not as "business as usual" because the probability of the scenario remains uncertain. According to Hausfather and Peter, SSP 5-8.5 could be described as low probability worst cases rather than as "business as usual" [35]. We did not introduce our results as the hydrological responses of the "business as usual" or worst-case scenario because our results describe the hydrological responses in Madagascar if the world would behave as simulated by SSP 5-8.5 and SSP 3-7.0. Despite the engagement of improvement of scenarios in CMIP6, future climate model developers should update the scenarios embedded in GCMs for an improvement in climate modeling, especially for the high-emission scenarios.

\section{Conclusions}

The impact of climate change on hydrology in the Mangoky river was assessed using ANN and SWAT hydrological models. We downscaled outputs from the latest climate model CMIP6 and simulated future precipitation and temperature. This study indicates that the maximum and minimum temperature will increase in the future, with a higher increment in the late 21st century. We also found that the precipitation will decrease in the 2040s but increase in the 2090s, which could be related to the precipitation anomalies expected in the late 21st century. Future changes in temperature and precipitation have a significant effect on the surface runoff; hence the average runoff will decrease significantly in the 2040s and 2090s. This research improved the understanding of the impacts of climate change on water resources and availability in semi-arid Africa. Our findings could be used to implement effective water resources management. However, future research should look into the influence of the change in land cover on water resources. Furthermore, future climate model developers should update the scenarios embedded in GCMs to improve climate modeling, especially for the high-emission scenarios.

Supplementary Materials: The following are available online at https://www.mdpi.com/article/ 10.3390/w13091239/s1. Table S1. List of predictors from NCEP/NCAR. Table S2. Soil code and lithology in the Mangoky region. Table S3. Correlation matrix between precipitation, maximum and minimum temperature. Values in bold are different from 0 with a significance level alpha $=0.05$. Figure S1. Land use and land cover in the Mangoky basin. Figure S2. Soil map in Mangoky basin. Figure S3. Structure of the ANN developed in this study. Figure S4. Conceptual model of the present study. Figure S5. Performance of the ANN (at Station id 214447). Equation (S1) Nash and Sutcliffe efficiency. Equation (S2) PBIAS.

Author Contributions: Conceptualization, M.F.R.T. and J.Z.; methodology M.F.R.T.; software, M.F.R.T.; validation, M.F.R.T., M.H.R. and J.Z.; data curation, M.F.R.T.; writing—original draft preparation, M.F.R.T.; writing—review and editing, M.F.R.T., M.H.R.; visualization, M.F.R.T., M.H.R.; supervision, J.Z. All authors have read and agreed to the published version of the manuscript.

Funding: This research was financially supported by the National Natural Science Foundation of China (No. 51878093) and the Major Project of Natural Science Foundation of Chongqing (cstc2018jszx-zdyfxmX0009).

Institutional Review Board Statement: Not applicable.

Informed Consent Statement: Not applicable.

Data Availability Statement: Data used in this study are available at https://esgf-node.llnl.gov/ projects/esgf-llnl/ accessed on 23 May 2020, https:/ / psl.noaa.gov/data/gridded/data.ncep.reanalysis. html accessed on 23 April 2020.

Acknowledgments: The authors are thankful to the World Climate Research Programme for developing CMIP6. We also acknowledge the Earth System Grid Federation (ESGF) and its sponsors for storing and giving total access to the CMIP6 outputs. 
Conflicts of Interest: The authors declare no conflict of interest.

\section{References}

1. Wang, J.; Hu, L.; Li, D.; Ren, M. Potential Impacts of Projected Climate Change under CMIP5 RCP Scenarios on Streamflow in the Wabash River Basin. Adv. Meteorol. 2020, 2020, 9698423. [CrossRef]

2. Aryal, A.; Shrestha, S.; Babel, M.S. Quantifying the sources of uncertainty in an ensemble of hydrological climate-impact projections. Theor. Appl. Clim. 2019, 135, 193-209. [CrossRef]

3. Almazroui, M.; Saeed, F.; Saeed, S.; Islam, M.N.; Ismail, M.; Klutse, N.A.B.; Siddiqui, M.H. Projected Change in Temperature and Precipitation Over Africa from CMIP6. Earth Syst. Environ. 2020, 4, 455-475. [CrossRef]

4. IPCC. Climate Change 2014: Synthesis Report. Contribution of Working Groups I, II and III to the Fifth Assessment Report of the Intergovernmental Panel on Climate Change; IPCC: Geneva, Switzerland, 2014.

5. Niang, I.; Abdrabo, M.; Essel, A.; Lennard, C.; Padgham, J.; Urquhart, P. Africa in Climate Change 2014: Impacts, Adaptation, and Vulnerability. Part B: Regional Aspects. Contribution of Working Group II to the Fifth Assessment Report of the Intergovernmental Panel on Climate Change; Cambridge University Press: Cambridge, UK, 2014.

6. Tanteliniaina, M.F.R.; Chen, J.; Adyel, T.M.; Zhai, J. Elevation Dependence of the Impact of Global Warming on Rainfall Variations in a Tropical Island. Water 2020, 12, 3582. [CrossRef]

7. Chen, Y.; Liu, A.; Cheng, X. Quantifying economic impacts of climate change under nine future emission scenarios within CMIP6. Sci. Total. Environ. 2020, 703, 134950. [CrossRef] [PubMed]

8. World Bank Group. Madagascar Climate Change and Health Diagnostic. Risks and Opportunities for Climate-Smart Health and Nutrition InvestmentRisks and Opportunities for Climate-Smart Health and Nutrition Investment; World Bank: Washington, DC, USA, 2018.

9. Tadross, M.; Randriamarolaza, L.; Yip, Z.K. Climate Change in Madagascar; Recent Past and Future; World Bank: Washington, DC, USA, 2008.

10. Rakotomavo, A.; Fromard, F. Dynamics of mangrove forests in the Mangoky River delta, Madagascar, under the influence of natural and human factors. For. Ecol. Manag. 2010, 259, 1161-1169. [CrossRef]

11. Daneshi, A.; Brouwer, R.; Najafinejad, A.; Panahi, M.; Zarandian, A.; Maghsood, F.F. Modelling the impacts of climate and land use change on water security in a semi-arid forested watershed using InVEST. J. Hydrol. 2021, 593, 125621. [CrossRef]

12. Molina-Navarro, E.; Hallack-Alegría, M.; Martínez-Pérez, S.; Ramírez-Hernández, J.; Mungaray-Moctezuma, A.; Sastre-Merlín, A. Hydrological modeling and climate change impacts in an agricultural semiarid region. Case study: Guadalupe River basin, Mexico. Agric. Water Manag. 2016, 175, 29-42. [CrossRef]

13. Sachindra, D.A.; Ahmed, K.; Rashid, M.; Shahid, S.; Perera, B.J.C. Statistical downscaling of precipitation using machine learning techniques. Atmos. Res. 2018, 212, 240-258. [CrossRef]

14. Taylor, K.E.; Stouffer, R.J.; Meehl, G.A. An Overview of CMIP5 and the Experiment Design. Bull. Am. Meteorol. Soc. 2012, 93, 485-498. [CrossRef]

15. Gusain, A.; Ghosh, S.; Karmakar, S. Added value of CMIP6 over CMIP5 models in simulating Indian summer monsoon rainfall Atmos. Res. 2020, 232, 104680. [CrossRef]

16. Maraun, D.; Wetterhall, F.; Ireson, A.M.; Chandler, R.E.; Kendon, E.J.; Widmann, M.; Brienen, S.; Rust, H.W.; Sauter, T.; Themeß1, M.; et al. Precipitation downscaling under climate change: Recent developments to bridge the gap between dynamical models and the end user. Rev. Geophys. 2010, 48, 3003. [CrossRef]

17. Wilby, R.L.; Dawson, C.W.; Barrow, E.M. Sdsm-A decision support tool for the assessment of regional climate change impacts. Environ. Model. Softw. 2002, 17, 145-157. [CrossRef]

18. Wilby, R.; Wigley, T. Downscaling general circulation model output: A review of methods and limitations. Prog. Phys. Geogr. Earth Environ. 1997, 21, 530-548. [CrossRef]

19. Fan, X.; Miao, C.; Duan, Q.; Shen, C.; Wu, Y. The Performance of CMIP6 Versus CMIP5 in Simulating Temperature Extremes Over the Global Land Surface. J. Geophys. Res. Atmos. 2020, 125. [CrossRef]

20. Zhai, J.; Mondal, S.K.; Fischer, T.; Wang, Y.; Su, B.; Huang, J.; Tao, H.; Wang, G.; Ullah, W.; Uddin, J. Future drought characteristics through a multi-model ensemble from CMIP6 over South Asia. Atmos. Res. 2020, 246, 105111. [CrossRef]

21. Zhu, Y.-Y.; Yang, S. Evaluation of CMIP6 for historical temperature and precipitation over the Tibetan Plateau and its comparison with CMIP5. Adv. Clim. Chang. Res. 2020, 11, 239-251. [CrossRef]

22. López-Ballesteros, A.; Senent-Aparicio, J.; Martínez, C.; Pérez-Sánchez, J. Assessment of future hydrologic alteration due to climate change in the Aracthos River basin (NW Greece). Sci. Total. Environ. 2020, 733, 139299. [CrossRef]

23. Bhatta, B.; Shrestha, S.; Shrestha, P.K.; Talchabhadel, R. Evaluation and application of a SWAT model to assess the climate change impact on the hydrology of the Himalayan River Basin. Catena 2019, 181, 104082. [CrossRef]

24. Deng, C.; Pisani, B.; Hernández, H.; Li, Y. Assessing the impact of climate change on water resources in a semi-arid area in central Mexico using a SWAT model. Boletín Soc. Geológica Mex. 2020, 72, A150819. [CrossRef]

25. Arnold, J.G.; Moriasi, D.N.; Gassman, P.W.; Abbaspour, K.C.; White, M.J.; Srinivasan, R.; Santhi, C.; Harmel, R.D.; Van Griensven, A.; Van Liew, M.W.; et al. SWAT: Model Use, Calibration, and Validation. Trans. ASABE 2012, 55, 1491-1508. [CrossRef]

26. Mahmoodi, N.; Wagner, P.D.; Kiesel, J.; Fohrer, N. Modeling the impact of climate change on streamflow and major hydrological components of an Iranian Wadi system. J. Water Clim. Chang. 2020, 2020098. [CrossRef] 
27. Rahman, K.; Ray, N.; Giuliani, G.; Maringanti, C.; George, C.; Lehmann, A. Breaking walls towards fully open source hydrological modeling. Water Resour. 2017, 44, 23-30. [CrossRef]

28. Abrahart, R.J.; Kneale, P.E.; See, L.M. Neural Networks for Hydrological Modeling; Taylor \& Francis: Hoboken, NJ, USA, 2004; ISBN 978-0-203-02411-9.

29. Nourani, V.; Paknezhad, N.J.; Sharghi, E.; Khosravi, A. Estimation of prediction interval in ANN-based multi-GCMs downscaling of hydro-climatologic parameters. J. Hydrol. 2019, 579, 124226. [CrossRef]

30. Vu, M.T.; Aribarg, T.; Supratid, S.; Raghavan, S.V.; Liong, S.-Y. Statistical downscaling rainfall using artificial neural network: Significantly wetter Bangkok? Theor. Appl. Clim. 2016, 126, 453-467. [CrossRef]

31. Seland, Ø.; Bentsen, M.; Olivié, D.; Toniazzo, T.; Gjermundsen, A.; Graff, L.S.; Debernard, J.B.; Gupta, A.K.; He, Y.-C.; Kirkevåg, A.; et al. Overview of the Norwegian Earth System Model (NorESM2) and key climate response of CMIP6 DECK, historical, and scenario simulations. Geosci. Model Dev. 2020, 13, 6165-6200. [CrossRef]

32. Swart, N.C.; Cole, J.N.S.; Kharin, V.V.; Lazare, M.; Scinocca, J.F.; Gillett, N.P.; Anstey, J.; Arora, V.; Christian, J.R.; Hanna, S.; et al. The Canadian Earth System Model version 5 (CanESM5.0.3). Geosci. Model Dev. 2019, 12, 4823-4873. [CrossRef]

33. Huang, J.; Qin, D.; Jiang, T.; Wang, Y.; Feng, Z.; Zhai, J.; Cao, L.; Chao, Q.; Xu, X.; Wang, G.; et al. Effect of Fertility Policy Changes on the Population Structure and Economy of China: From the Perspective of the Shared Socioeconomic Pathways. Earth's Future 2019, 7, 250-265. [CrossRef]

34. Eyring, V.; Bony, S.; Meehl, G.A.; Senior, C.A.; Stevens, B.; Stouffer, R.J.; Taylor, K.E. Overview of the Coupled Model Intercomparison Project Phase 6 (CMIP6) experimental design and organization. Geosci. Model Dev. 2016, 9, 1937-1958. [CrossRef]

35. Hausfather, Z.; Peters, G.P. Emissions-The 'business as usual' story is misleading. Nature 2020, 577, 618-620. [CrossRef]

36. O'Neill, B.C.; Kriegler, E.; Ebi, K.L.; Kemp-Benedict, E.; Riahi, K.; Rothman, D.S.; Van Ruijven, B.J.; Van Vuuren, D.P.; Birkmann, J.; Kok, K.; et al. The roads ahead: Narratives for shared socioeconomic pathways describing world futures in the 21st century. Glob. Environ. Chang. 2017, 42, 169-180. [CrossRef]

37. Arnold, J.; Allen, P. Estimating hydrologic budgets for three Illinois watersheds. J. Hydrol. 1996, 176, 57-77. [CrossRef]

38. Graham, L.P.; Andréasson, J.; Carlsson, B. Assessing climate change impacts on hydrology from an ensemble of regional climate models, model scales and linking methods-A case study on the Lule River basin. Clim. Chang. 2007, 81, 293-307. [CrossRef]

39. Ahmadi, M.; Vaziri, B.M.; Ahmadi, H.; Moeini, A.; Zehtabiyan, G.R. Assessment of climate change impact on surface runoff, statistical downscaling and hydrological modeling. Phys. Chem. Earth Parts A/B/C 2019, 114, 102800. [CrossRef]

40. Campozano, L.; Tenelanda, D.; Sanchez, E.; Samaniego, E.; Feyen, J. Comparison of Statistical Downscaling Methods for Monthly Total Precipitation: Case Study for the Paute River Basin in Southern Ecuador. Adv. Meteorol. 2016, 2016, 1-13. [CrossRef]

41. Rashid, M.; Beecham, S.; Chowdhury, R.K. Statistical downscaling of rainfall: A non-stationary and multi-resolution approach. Theor. Appl. Climatol. 2016, 124, 919-933. [CrossRef]

42. Sharghi, E.; Nourani, V.; Najafi, H.; Gokcekus, H. Conjunction of a newly proposed emotional ANN (EANN) and wavelet transform for suspended sediment load modeling. Water Supply 2019, 19, 1726-1734. [CrossRef]

43. Sharghi, E.; Nourani, V.; Najafi, H.; Molajou, A. Emotional ANN (EANN) and Wavelet-ANN (WANN) Approaches for Markovian and Seasonal Based Modeling of Rainfall-Runoff Process. Water Resour. Manag. 2018, 32, 3441-3456. [CrossRef]

44. Sheela, K.G.; Deepa, S.N. Review on Methods to Fix Number of Hidden Neurons in Neural Networks. Math. Probl. Eng. 2013, 2013, 425740. [CrossRef]

45. Neitsch, S.L.; Arnold, J.G.; Kiniry, J.R.; Williams, J.R. Soil and Water Assessment Tool: Theoretical Documentation, Version 2009; A\&M University: College Station, TX, USA, 2011.

46. Kalin, L.; Isik, S.; Schoonover, J.E.; Lockaby, B.G. Predicting Water Quality in Unmonitored Watersheds Using Artificial Neural Networks. J. Environ. Qual. 2010, 39, 1429-1440. [CrossRef]

47. Yang, C.; Wang, N.; Wang, S.; Zhou, L. Performance comparison of three predictor selection methods for statistical downscaling of daily precipitation. Theor. Appl. Clim. 2018, 131, 43-54. [CrossRef]

48. Haile, G.G.; Tang, Q.; Hosseini-Moghari, S.; Liu, X.; Gebremicael, T.G.; Leng, G.; Kebede, A.; Xu, X.; Yun, X. Projected Impacts of Climate Change on Drought Patterns Over East Africa. Earth's Future 2020, 8. [CrossRef]

49. Tan, G.; Ayugi, B.; Ngoma, H.; Ongoma, V. Projections of future meteorological drought events under representative concentration pathways (RCPs) of CMIP5 over Kenya, East Africa. Atmos. Res. 2020, 246, 105112. [CrossRef]

50. Dunning, C.M.; Black, E.; Allan, R.P. Later Wet Seasons with More Intense Rainfall over Africa under Future Climate Change. J. Clim. 2018, 31, 9719-9738. [CrossRef]

51. Pohl, B.; Macron, C.; Monerie, P.-A. Fewer rainy days and more extreme rainfall by the end of the century in Southern Africa. Sci. Rep. 2017, 7, 46466. [CrossRef] [PubMed]

52. Seneviratne, S.I.; Nicholls, N.; Easterling, D.; Goodess, C.M.; Kanae, S.; Kossin, J.; Luo, Y.; Marengo, J.; McInnes, K.; Rahimi, M.; et al. Changes in climate extremes and their impacts on the natural physical environment. In Managing the Risks of Extreme Events and Disasters to Advance Climate Change Adaptation. A Special Report of Working Groups I and II of the Intergovernmental Panel on Climate Change; Cambridge University Press: Cambridge, UK, 2012; pp. 109-230.

53. Vizy, E.K.; Cook, K.H. Mid-Twenty-First-Century Changes in Extreme Events over Northern and Tropical Africa. J. Clim. 2012, 25, 5748-5767. [CrossRef]

54. Nematchoua, M.K.; Ricciardi, P.; Orosa, J.A.; Buratti, C. A detailed study of climate change and some vulnerabilities in Indian Ocean: A case of Madagascar island. Sustain. Cities Soc. 2018, 41, 886-898. [CrossRef] 
55. Araya-Osses, D.; Casanueva, A.; Román-Figueroa, C.; Uribe, J.M.; Paneque, M. Climate change projections of temperature and precipitation in Chile based on statistical downscaling. Clim. Dyn. 2020, 54, 4309-4330. [CrossRef]

56. James, R.; Washington, R. Changes in African temperature and precipitation associated with degrees of global warming. Clim. Chang. 2012, 117, 859-872. [CrossRef]

57. Bates, B.C.; Kundzewicz, Z.W.; Wu, S.; Palutikof, J.P. Climate Change and Water. Technical Paper of the Intergovernmental Panel on Climate Change; IPCC: Geneva, Switzerland, 2008; p. 210.

58. Chemura, A.; Rwasoka, D.; Mutanga, O.; Dube, T.; Mushore, T. The impact of land-use/land cover changes on water balance of the heterogeneous Buzi sub-catchment, Zimbabwe. Remote. Sens. Appl. Soc. Environ. 2020, 18, 100292. [CrossRef]

59. Näschen, K.; Diekkrüger, B.; Evers, M.; Höllermann, B.; Steinbach, S.; Thonfeld, F. The Impact of Land Use/Land Cover Change (LULCC) on Water Resources in a Tropical Catchment in Tanzania under Different Climate Change Scenarios. Sustainability 2019, 11, 7083. [CrossRef]

60. Pielke, R.; Ritchie, J. Distorting the view of our climate future: The misuse and abuse of climate pathways and scenarios. Energy Res. Soc. Sci. 2021, 72, 101890. [CrossRef]

61. Burgess, M.G.; Ritchie, J.; Shapland, J.; Pielke, R. IPCC baseline scenarios have over-projected $\mathrm{CO}_{2}$ emissions and economic growth. Environ. Res. Lett. 2020, 16, 014016. [CrossRef] 